\title{
Mg-Al and Zn-Al Layered Double Hydroxides Promote Dynamic Expression of Marker Genes in Osteogenic Differentiation by Modulating Mitogen-Activated Protein Kinases
}

\author{
Ha Ram Kang, Célio Junior da Costa Fernandes, Rodrigo Augusto da Silva, \\ Vera Regina Leopoldo Constantino, Ivan Hong Jun Koh, and Willian F. Zambuzzi*
}

The effect of LDH samples comprised of chloride anions intercalated between positive layers of magnesium/aluminum (Mg-Al LDH) or zinc/aluminum ( $\mathrm{Zn-Al}$ LDH) chemical composition on pre-osteoblast performance is investigated. Non-cytotoxic concentrations of both LDHs modulated pre-osteoblast adhesion by triggering cytoskeleton rearrangement dependent on recruiting of Cofilin, which is modulated by the inhibition of the Protein Phosphatase 2A (PP2A), culminating in osteoblast differentiation with a significant increase of osteogenic marker genes. The alkaline phosphatase (ALP) and bone sialoprotein (BSP) are significantly up-modulated by both LDHs; however, Mg-Al LDH nanomaterial promoted even more significance than both experimental controls, while the phosphorylations of mitogen-activated protein kinase (MAPKs)- extracellular signal-regulated kinases (ERK) and c-Jun $\mathrm{N}$-terminal kinase (JNK) significantly increased. MAPK signaling is necessary to activate Runt-related transcription factor 2 (RUNX2) gene. Concomitantly, it is also investigated whether challenged osteoblasts are able to modulate osteoclastogenesis by investigating both osteoprotegerin (OPG) and Receptor activator of nuclear factor kappa-ligand (RANKL) in this model; a dynamic reprogramming of both these genes is found, suggesting LDHs in modulating osteoclastogenesis. These results suggest that LDHs interfere in bone remodeling, and they can be considered as nanomaterials in graft-based bone healing or drug-delivery materials for bone disorders.

\section{Introduction}

Bone defects are one of the most pressing problems in the medical-dental area. ${ }^{[1,2]}$ Reconstruction of injured tissue is one of the greatest challenges for surgeons, and application of a biomaterial is often necessary for adequate tissue regeneration. ${ }^{[3]}$ Specific to bone, the therapeutic biomaterial should have osteopromotive characteristics, which facilitate the differentiation of undifferentiated cells in mature osteoblasts. ${ }^{[4]}$ In turn, osteoblasts are a terminally differentiated form of preosteoblasts (pre-Obs) and are responsible for bone formation by sequentially producing bone matrix proteins, which subsequently induce tissue mineralization. ${ }^{[5,6]}$

Layered double hydroxides (LDHs) can be described as a class of inorganic materials $2 \mathrm{D}$ organized with anion exchange properties and an interesting equilibrium between chemical stability and biodegradability. A synthetic $\mathrm{LDH}$ with composition $\left[\mathrm{Mg}_{6} \mathrm{Al}_{2}(\mathrm{OH})_{16}\right] \mathrm{CO}_{3} \cdot 4 \mathrm{H}_{2} \mathrm{O}$, and known as hydrotalcite, is used commercially as the antacid Talcid. ${ }^{[7]}$ In the $1990 \mathrm{~s}$, several papers showed the efficacy of Talcid compared to other antacids already well known in the market through in vitro and in vivo tests. ${ }^{[8-10]}$ These studies showed the efficacy of hydrotalcite in the gastric mucosal protection, angiogenesis activation of wounded mucosa, healing of gastroduodenal ulcers, and progress in the aspect of mucosal scar. In addition to its acid neutralization effect, Talcid can activate genes for epidermal growth factor as well as its receptor in normal and ulcerated gastric mucosa.

LDHs exhibit the $\left[\mathrm{M}^{\mathrm{II}}{ }_{(1-x)} \mathrm{M}^{\mathrm{III}}{ }_{x}(\mathrm{OH})_{2}\right]^{x+}\left(\mathrm{A}^{m-}\right)_{x / \mathrm{m}} \cdot n \mathrm{H}_{2} \mathrm{O}$ general formula where $\mathrm{M}^{\mathrm{II}}$ and $\mathrm{M}^{\mathrm{III}}$ are di- and trivalent cations
H. R. Kang, C. J. da Costa Fernandes, R. A. da Silva, Prof. W. F. Zambuzzi

Laboratorio de Bioensaios e Dinâmica Celular

Departamento de Química e Bioquímica

Instituto de Biociências

Universidade Estadual Paulista-UNESP

campus Botucatu, São Paulo CEP 18618-970, Brazil

E-mail:wzambuzzi@ibb.unesp.br

The ORCID identification number(s) for the author(s) of this article can be found under https://doi.org/10.1002/adhm.201700693.

DOI: 10.1002/adhm.201700693

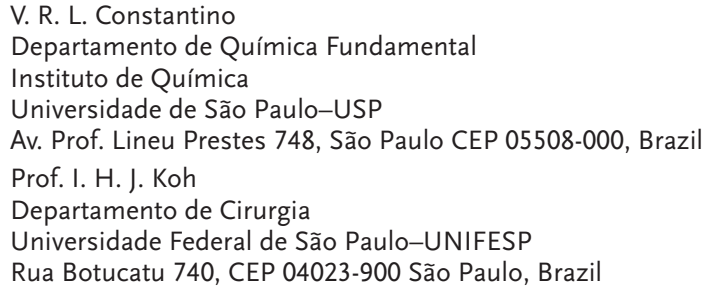


a

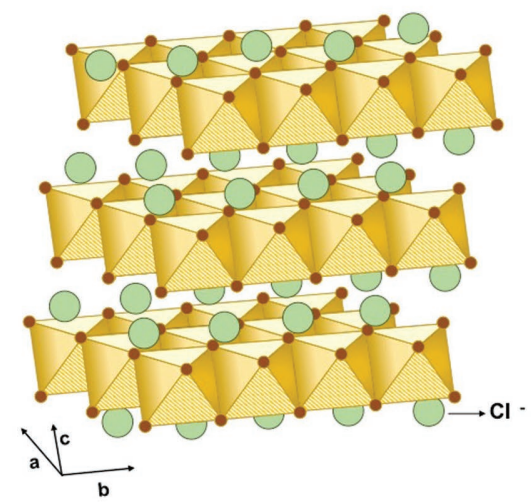

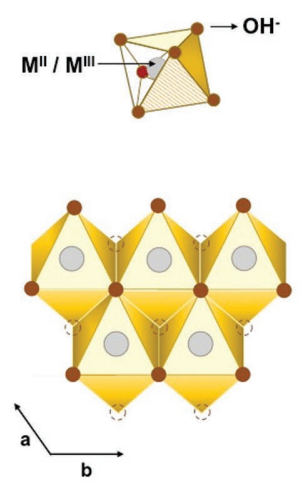

b

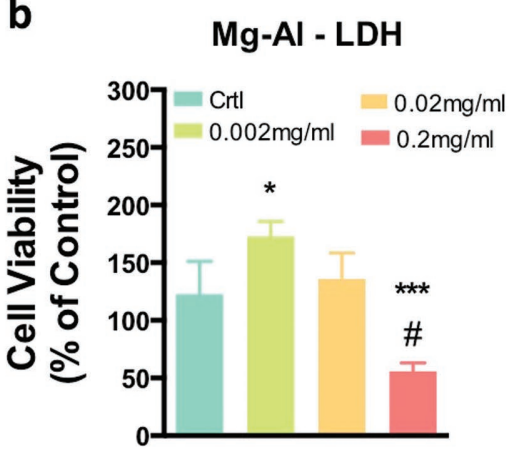

C

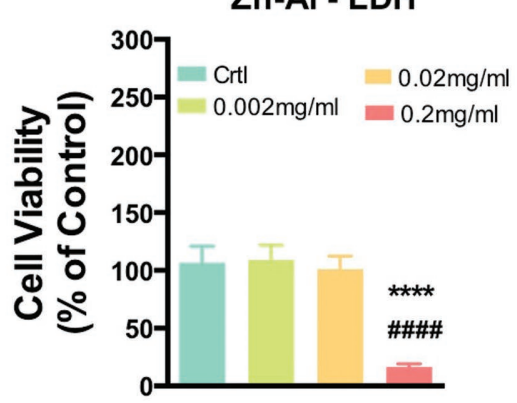

Figure 1. Schematic representation of LDH structures and their cytotoxicity. a) Each octahedral unit has six hydroxide ions coordinated to the metal cation in the central site; each hydroxide ion is shared by three octahedrons (or three metal ions). The layers are in [ab] plane while assembling of the layers is accomplished in the $c$ axis direction. To investigate the cytotoxic effect of LDHs, pre-Obs were plated and in the semiconfluence were subjected with different concentrations of LDHs, as shown. Pre-Obs were treated with conventional medium for the control group; b) Mg-Al LDH diluted in three different concentrations $(0.002 ; 0.02 ; 0.2 \mathrm{mg})$ and c) $\mathrm{Zn}-\mathrm{Al}$ LDH diluted in three different concentrations $(0.002 ; 0.02 ; 0.2 \mathrm{mg})$. * $p<0.05 ; * * * p<$

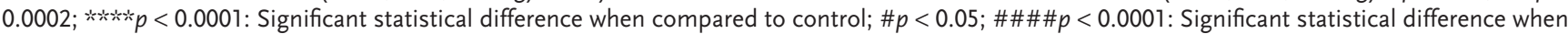
comparing $\mathrm{Mg}_{2} \mathrm{Al}-\mathrm{Cl} 0.2 \mathrm{mg}$ and $\mathrm{Mg}_{2} \mathrm{Al}-\mathrm{Cl} 0.02-0.002 \mathrm{mg}$.

positioned in octahedral $\left[\mathrm{M}(\mathrm{OH})_{6}\right]$ units share edges in an layered fashion (Figure 1a), while A represents an anion of valence $m$ that is sandwiched between the layers, neutralizing their electrical positive charges (simplified notation is $\mathrm{M}^{\mathrm{II}}{ }_{R} \mathrm{M}^{\mathrm{III}}-\mathrm{A}$, where $R$ is the $\mathrm{M}^{\mathrm{II}} / \mathrm{M}^{\mathrm{III}}$ molar ratio). ${ }^{[11]}$ Usually, the interlayer spaces and the external surfaces of LDHs are occupied by water molecules. The distance between the stacking layers can be modified to accommodate anions of different sizes, electrical charges, and chemical nature (inorganic or organic).

Considering the possibility of controlling the chemical composition of LDH layers and their affinity for anions, drugs, and other biological bioactive species, they have been confined between the inorganic layers for drug delivery and imaging. ${ }^{12-15]}$ Our group has been studying experimental parameters for the intercalation of drugs such as pravastatin ${ }^{[16]}$ and sulindac into LDHs and applying structural, spectroscopic, textural, and thermal techniques for their detailed characterization. ${ }^{[17,18]}$ We recently reported the biological properties of a LDHs intercalated with the anion of mefenamic acid evaluated through the in vitro cytotoxicity tests by hemolysis, and in vivo tests concerning the anti-inflammatory activity and nociceptive effect of the intercalated and nonintercalated drug. ${ }^{[19]}$ The mefenamate confinement in the LDH structure decreased its hemolytic effect and potentiated its anti-inflammatory and analgesic effects. In another study, the biocompatibility of LDH containing magnesium and zinc as divalent as aluminum as trivalent metal (chloride as intercalated anion) was investigated by histology and microcirculatory dynamic imaging, through sidestream dark field imaging, after implantation into the abdominal wall of rats. ${ }^{[20]}$ Remarkable biocompatibility, rapid induction of fibroblast proliferation, neovascularization, and subsequent collagen production in vivo assays were observed.

Studies focusing on the action of LDHs on bone cells are very scarce. ${ }^{[21,22]}$ Hence, we investigated the effect of LDH materials on preosteoblast metabolism, mainly addressing their possibility to modulate the expression of osteogenic differentiation genes. Summarizing, our results showed that both LDHs assayed here were able to modulate osteoblast metabolism, further compromising osteoclastogenesis. Importantly, we report for the first time, the acquisition of osteogenic phenotype by LDHs in a mitogen-activated protein kinase (MAPK)-dependent manner. Thus, these results suggest LDHs as very interesting nanomaterials to be explored in bone bioengineering as a scaffold or drug-delivery materials for bone disorders.

\section{Results}

LDH samples were prepared and characterized as previously described. ${ }^{[12]}$ According to data analysis, the chemical 
formulae $\left[\mathrm{Mg}_{2.10} \mathrm{Al}(\mathrm{OH})_{6.20}\right] \mathrm{Cl} \cdot 2.3 \mathrm{H}_{2} \mathrm{O}$ and $\left[\mathrm{Zn}_{2.08} \mathrm{Al}(\mathrm{OH})_{6.16}\right]$ $\mathrm{Cl} \cdot 1.7 \mathrm{H}_{2} \mathrm{O}$ (abbreviated $\mathrm{Mg}_{2} \mathrm{Al}-\mathrm{Cl}$ and $\mathrm{Zn}_{2} \mathrm{Al}-\mathrm{Cl}$ ) were proposed. Zeta potential measurements of the $\mathrm{LDH}$ suspensions in water gave the values $+41.7 \mathrm{mV}$ for $\mathrm{Mg}_{2} \mathrm{Al}-\mathrm{Cl}$ and $+46 \mathrm{mV}$ for $\mathrm{Zn}_{2} \mathrm{Al}-\mathrm{Cl}$.

Thereafter, both LDH samples were diluted in cell culture medium $\left(0.002,0.02\right.$, and $\left.0.2 \mathrm{mg} \mathrm{mL}^{-1}\right)$ to treat preosteoblasts in vitro to determine their cytotoxicity. After $24 \mathrm{~h}$ of treatment, the cell viability test was performed by 3-(4,5-dimethylthiazol-2-yl)-2,5-diphenyltetrazolium bromide (MTT) reduction (vital dye able to be reduced by mitochondrial dehydrogenases). This showed that cell viability decreased around $20 \%$ compared to control when the concentration of both LDHs was $0.2 \mathrm{mg} \mathrm{mL}^{-1}$ (Figure 1b,c). However, at $0.002 \mathrm{mg} \mathrm{mL}^{-1}$, both LDHs did not present any cytotoxicity, but $\mathrm{Mg}_{2} \mathrm{Al}-\mathrm{Cl}$ promoted a significant increase of dehydrogenase activities (Figure 1b).

\subsection{LDH Materials Affect Preosteoblast Adhesion by Modulating Cofilin and PP2A Phosphorylations}

To evaluate the first effect of $\mathrm{LDH}$ on pre-Ob adhesion, the cells were subjected to both LDHs separately up to $24 \mathrm{~h}$, then the cells were trypsinized, counted, and replated. After 3 and $24 \mathrm{~h}$, the adherent cells were stained with violet crystal, which allowed us to estimate cell adhesion in response to LDH (Figure 2a,b). After the first $3 \mathrm{~h}$ of adhesion, LDH containing

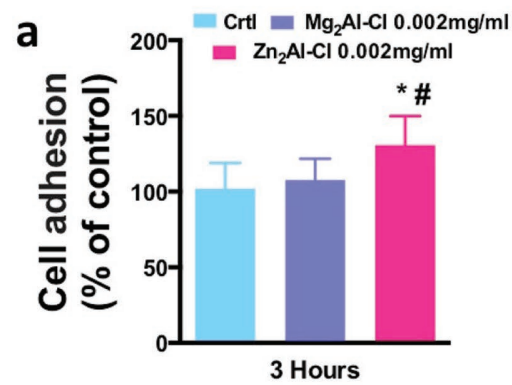

C
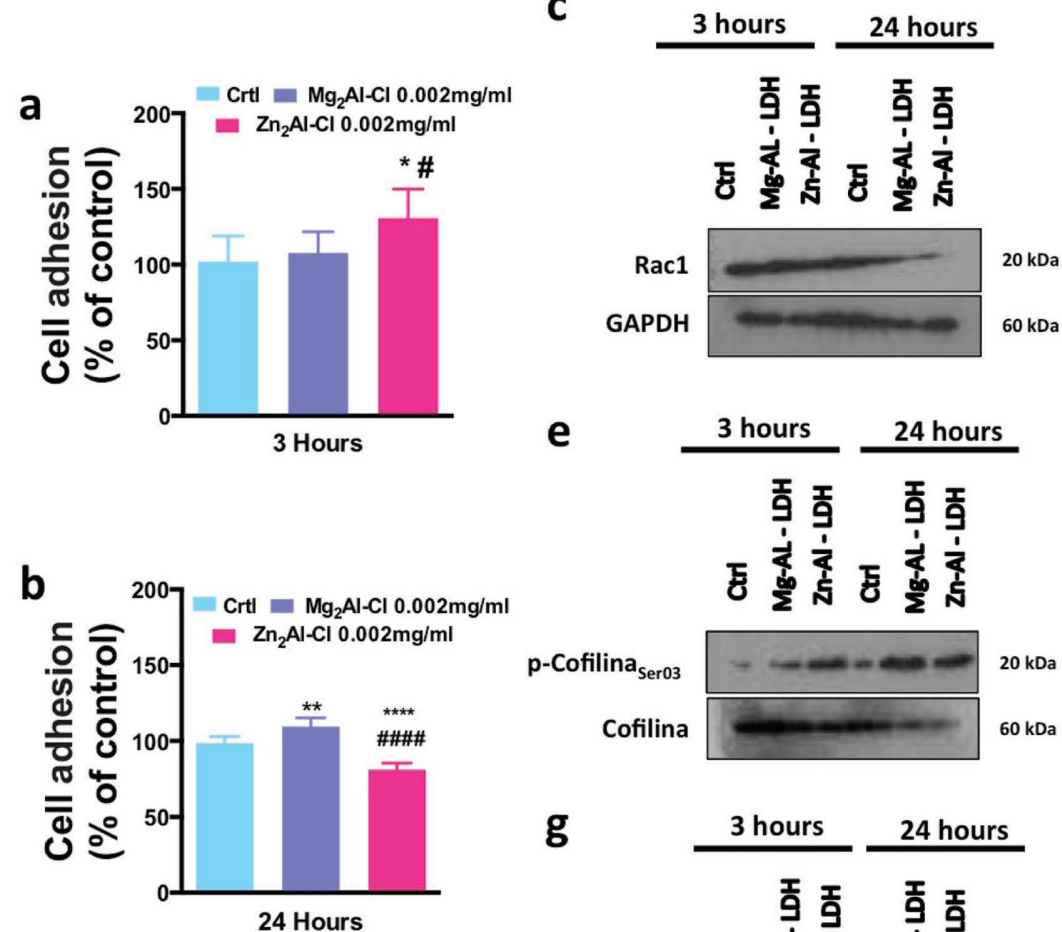
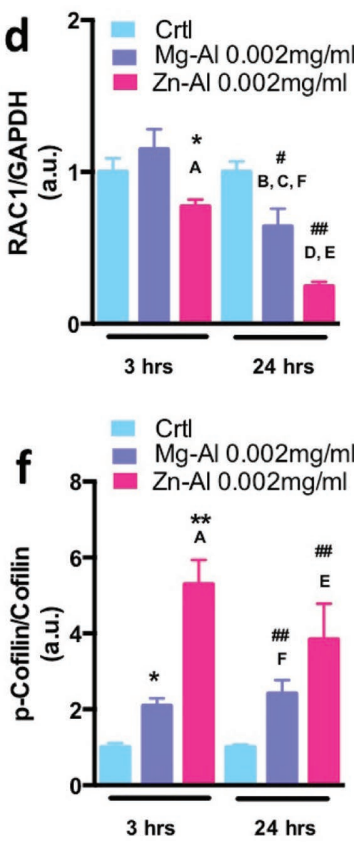

e

g
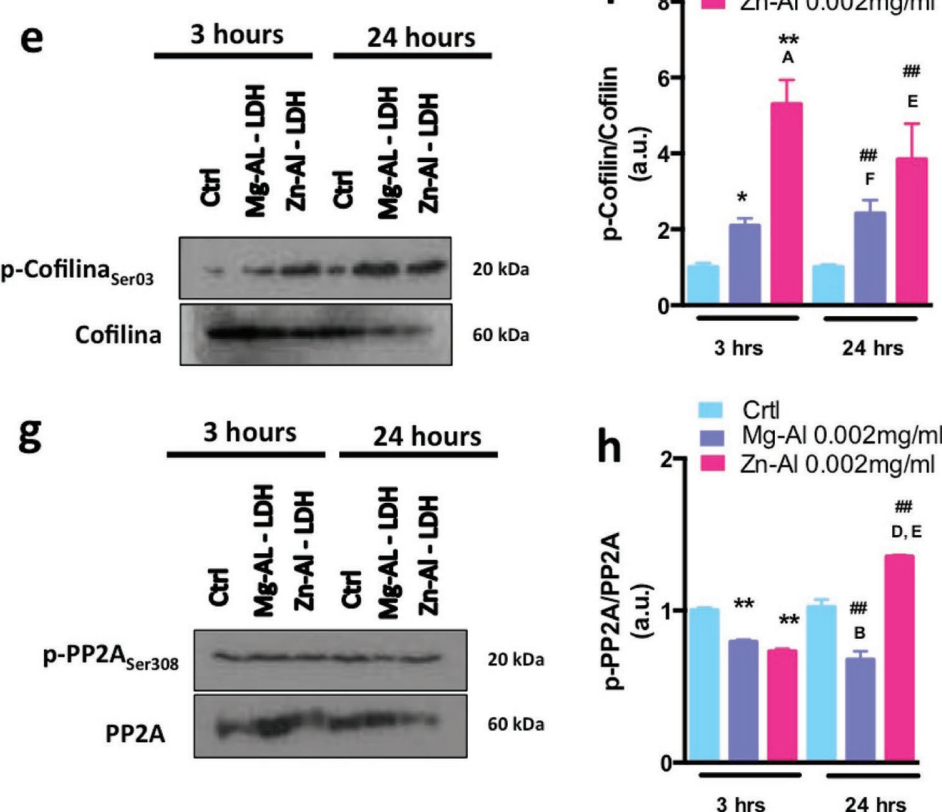

Figure 2. LDH impacts pre-Ob adhesion by modulating Cofilin/PP2A balance. Pre-Ob maintained with conventional medium was the control group. $\mathrm{a}$,b) First, cell adhesion was measured by vital violet crystal after 3 and $24 \mathrm{~h}$ of plating, where treatments were made at a concentration of $0.002 \mathrm{mg} \mathrm{mL}^{-1}$, as suggested previously as a subtoxic concentration. Thereafter, immunoblots showed the profile of phosphorylation of cofilin and PP2A, and Rac- 1 expression. Representative results are depicted and the graphs represent arbitrary values obtained by a densitometric analysis of bands normalized by the mean values of the respective GADPH (internal control) bands. c,d) Expression analysis of Racl; e,f) analysis of p-Cofilin/Cofilin ratio; and $\mathrm{g}, \mathrm{h})$ analysis of the expression of p-PP2A/PP2A ratio. Statistical significances were considered when: $* * p<0.0017 ; * * * p<0.0002 ; * * * * p<0.0001:$. $\# p<0.05$; \#\#\#\#p<0.0001. Statistical significances were considered when comparing $\mathrm{Mg}_{2} \mathrm{Al}-\mathrm{Cl} 0.2 \mathrm{mg}$ and $\mathrm{Mg}_{2} \mathrm{Al}-\mathrm{Cl} 0.02-0.002 \mathrm{mg}$. (a) $p<0.05$ : Significant statistical difference when comparing $\mathrm{Mg}_{2} \mathrm{Al}-\mathrm{Cl} 3 \mathrm{~h}$ and $\mathrm{Zn}_{2} \mathrm{Al}-\mathrm{Cl} 3 \mathrm{~h}$. (b) $p<0.05$ : Significant statistical difference when comparing $\mathrm{Mg} \mathrm{g}_{2} \mathrm{Al}-\mathrm{Cl}$ $24 \mathrm{~h}$ and $\mathrm{Zn}_{2} \mathrm{Al}-\mathrm{Cl} 24 \mathrm{~h}$. (c) Significant statistical difference when comparing $\mathrm{Mg}_{2} \mathrm{Al}-\mathrm{Cl} 3 \mathrm{~h}$ and $\mathrm{Mg}_{2} \mathrm{Al}-\mathrm{Cl} 24 \mathrm{~h}$. (d) $p<0.0017$ : Significant statistical difference when comparing $\mathrm{Zn}_{2} \mathrm{Al}-\mathrm{Cl} 3 \mathrm{~h}$ and $\mathrm{Zn}_{2} \mathrm{Al}-\mathrm{Cl} 24 \mathrm{~h}$. (e) $p<0.0002$ : Significant statistical difference when comparing $\mathrm{Mg}_{2} \mathrm{Al}-\mathrm{Cl} 3 \mathrm{~h}$ and $\mathrm{Zn}{ }_{2} \mathrm{Al}-\mathrm{Cl}$ $24 \mathrm{~h}$. (f) Significant statistical difference when comparing $\mathrm{Zn}_{2} \mathrm{Al}-\mathrm{Cl} 3 \mathrm{~h}$ and $\mathrm{Mg}_{2} \mathrm{Al}-\mathrm{Cl} 24 \mathrm{~h}$. 
$\mathrm{Zn}^{2+}\left(\mathrm{Zn}_{2} \mathrm{Al}-\mathrm{Cl}\right)$ significantly upmodulated pre-Ob adhesion, while cells treated with $\mathrm{Mg}^{2+}\left(\mathrm{Mg}_{2} \mathrm{Al}-\mathrm{Cl}\right)$ remained unchanged. After $24 \mathrm{~h}$, the same procedure was carried out, and LDHs produced an inverse effect; $\mathrm{Mg}_{2} \mathrm{Al}-\mathrm{Cl}$ upmodulated pre-Ob adhesion, $\mathrm{Zn}_{2} \mathrm{Al}-\mathrm{Cl}$ downmodulated it (Figure 2a,b).

Later, we investigated how the molecular machinery was involved during pre-Ob adhesion at 3 and $24 \mathrm{~h}$, mainly with regard to the signaling protein involved with cytoskeleton rearrangement, which was previously proposed to be a pre-Ob adhesion biomarker. ${ }^{[23-25]}$ Our results found that Rac-1 decreased in response to both evaluated LDHs at both chosen experimental times (Figure 2c,d).

Additionally, the phosphorylation of Cofilin significantly increased in response to both LDHs, with very similar phosphorylation profile at both 3 and $24 \mathrm{~h}$ (Figure $2 \mathrm{e}, \mathrm{f}$ ). $\mathrm{Zn}_{2} \mathrm{Al}-\mathrm{Cl}$ produced a more significant response, which was greater at $3 \mathrm{~h}$ than at $24 \mathrm{~h}$ (Figure 2e,f). The Mg-doped LDHs produced a similar response at both 3 and $24 \mathrm{~h}$, which were significantly different than control (Figure 2e,f).

Finally, we investigated the involvement of PP2A, a very important Ser/Thr phosphatase able to modulate Cofilin phosphorylation balance by hydrolyzing the phosphoryl moiety from the phosphorylated protein, during pre-Ob adhesion. The phosphorylation of PP2A was assayed at Y307, a well-known inhibitory phosphorylation site of PP2A. Our results showed that the phospho-PP2A/PP2A ratio was decreased at $3 \mathrm{~h}$ of cell adhesion in response to both the LDHs assayed (Figure $2 \mathrm{~g}, \mathrm{~h}$ ). However, at $24 \mathrm{~h}$, it was significantly increased in response to $\mathrm{Zn}_{2} \mathrm{Al}-\mathrm{Cl}$ (Figure 2g,h).

\subsection{LDH Materials Require MAPK Activations during Osteogenic Pathway}

Next, we focused on the possibility that LDHs promote pre-Ob differentiation. We experimentally treated pre-Ob with both the LDH nanohybrids, separately up to $14 \mathrm{~d}$, when it was possible to determine the osteogenic phenotype, as detailed elsewhere. After $14 \mathrm{~d}$, biological samples were collected and used for different technologies. First, we focused on understanding whether AKT and MAPKs are required in response to LDHs. MAPKs in osteoblasts are critical transducers able to maintain bone mass. ${ }^{[26]}$ Our result clearly showed that phosphorylation of $\mathrm{AKT}$ was downregulated, but required, in response to both LDH materials (Figure 3a,b). The very similar profile was also seen in response to the positive control, where the cells were treated with osteogenic medium. Importantly, both MAPKs p44/p42 extracellular signal-regulated kinase (ERK)

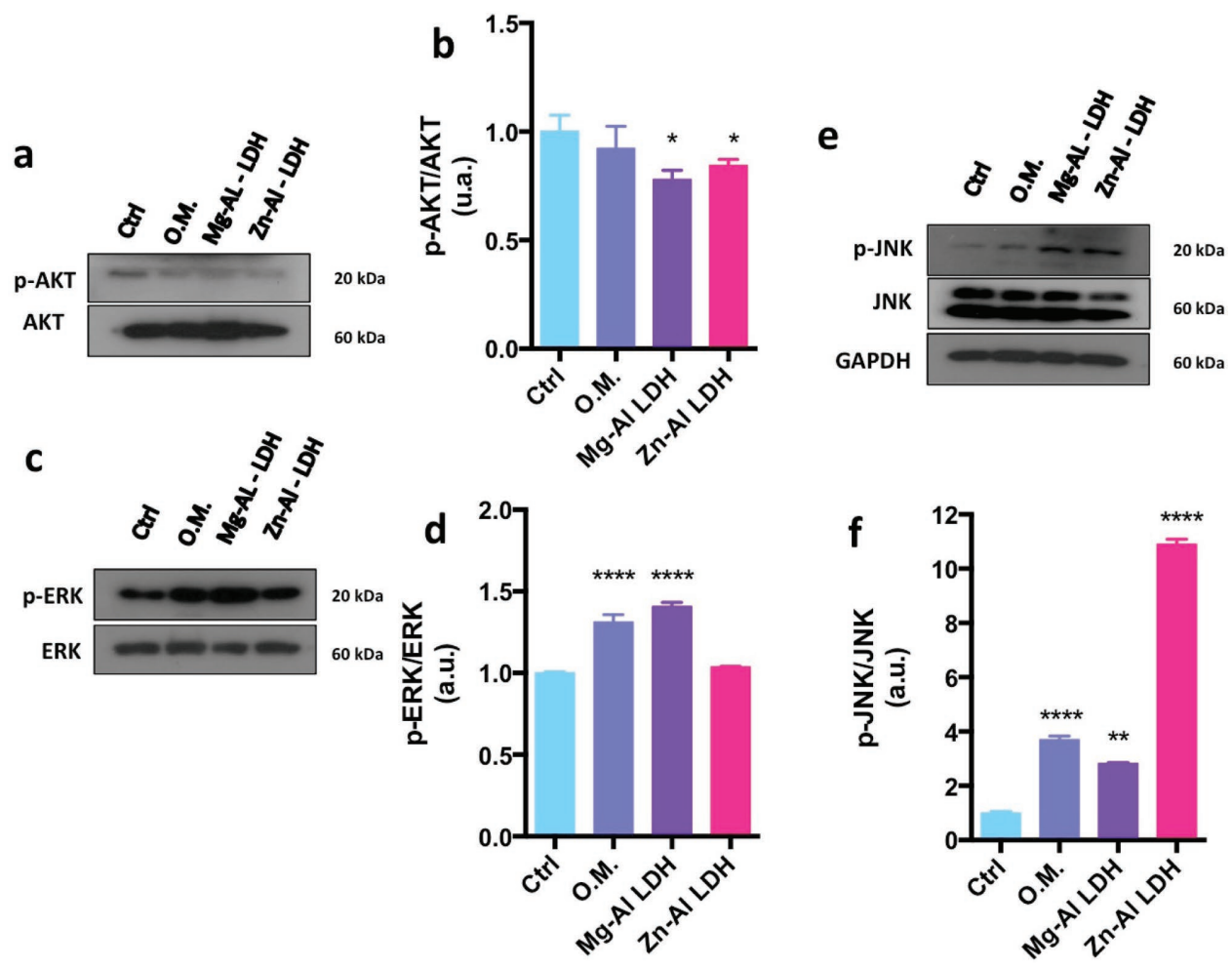

Figure 3. LDHs promote osteoblastic differentiation by upactivating both MAPKs - ERK and JNK. Pre-Obs were plated and at semiconfluence were treated with different experimental condition, as follows: control group, osteogenic medium (O.M.), $\mathrm{Mg}_{2} \mathrm{Al}-\mathrm{Cl}$, and $\mathrm{Zn}{ }_{2} \mathrm{Al}-\mathrm{Cl}$. After $14 \mathrm{~d}$ of treatment, the cells were scraped then lysed using standard lysing buffer (as described in detail in the Experimental Section), and the pooled protein was resolved on SDS-PAGE gel. After polyvinylidene difluoride (PVDF) membrane transferring, cells were incubated using specific primary antibody in western blotting technology. The proteins investigated were: a,b) AKT; MAPKs c,d) ERK and e,f) JNK. Representative blottings are shown, and the graphs represent arbitrary values obtained by densitometric analysis of bands normalized by the average values of the respective GADPH bands (housekeeping control). $* p<0.05 ; * * p<0.015 ; * *_{*} * p<0.0001$ : Significant statistical difference when compared to control. 
(Figure 3c,d) and c-jun N-terminal kinase (JNK) (Figure 3e,f) were significantly upmodulated in response to both the $\mathrm{LDH}$ samples.

\subsection{LDH-Induced Extracellular Matrix (ECM) Remodeling Requires Dynamic Matrix Metalloproteinases (MMPs) and Their Inhibitor Gene Reprograming}

Additionally, we focused on understanding whether the ECM remodeling mechanism was modulated by LDH. We stained ECM cells with three different protocols to verify the behavior of the cells and in vitro-secreted extracellular matrix. Hematoxylin \& eosin staining suggests a loose connective tissue in response to both LDH samples (Figure 4a), which was validated by Picrosirius red staining (Figure 4a,b). At this point, there was a significant staining on collagen fibers in response to both LDHs (Figure 4b), which was lower in response to $\mathrm{Mg}-\mathrm{Al} \mathrm{LDH}$.
These results prompted us to investigate whether ECM remodeling-related genes were involved, and we found dynamic gene reprograming in response to both LDHs (Figure 4). ECM serves diverse functions and is a major component of the cellular microenvironment, ${ }^{[27]}$ and its remodeling is mainly governed by MMPs and their tissue inhibitors (tissue inhibitors of matrix metalloproteinases (TIMPs) and reversion-inducingcysteine-rich protein with kazal motifs (RECK)). Thus, it is reasonable to suggest the modulation of MMPs, TIMPs, and $R E C K$ in response to LDHs, because they are involved with the development of mineralized tissue. ${ }^{[28-30]} \mathrm{Mg}-\mathrm{Al} \mathrm{LDH}$ promoted a significant upexpression of MMP9 and TIMP1, while MMP2, TIMP2, and RECK remained very similar to the control group (Figure 4c-g). With Zn-Al LDH, there was significant upactivation of MMP2, while all those MMP-related inhibitors evaluated here were upmodulated (Figure 4c-g). Differential modulation of ECM remodeling-related genes occurred with both LDHs, which suggests lower activity of MMPs in response to $\mathrm{Zn}-\mathrm{Al}$ $\mathrm{LDH}$, as all MMP inhibitors were upexpressed, impairing MMP

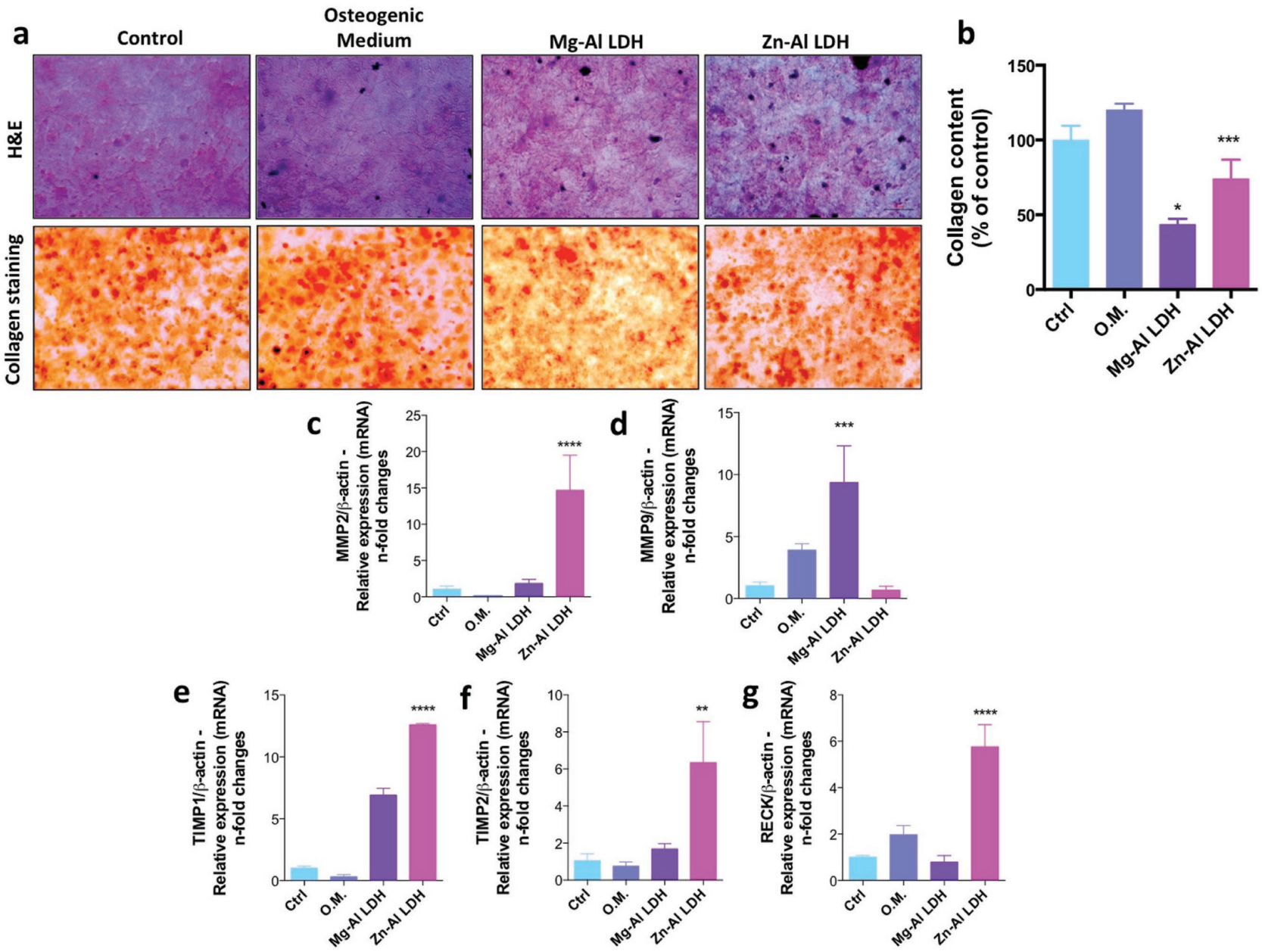

Figure 4. LDHs promote ECM remodeling during osteoblast differentiation. We evaluated ECM remodeling by first staining the cells with a) hematoxylin \& eosin and b) collagen fibers (Picro siruis). As ECM-remodeling seemed to be modulated by LDHs, we investigated whether MMPs and their inhibitors were required in response to LDHs. The cells were cultured up to $14 \mathrm{~d}$, when the total mRNA was collected and forwarded to quantitative polymerase chain reaction ( $\mathrm{QPCR}$ ) technology. ECM remodeling-related genes were investigated as follows: c) MMP2, d) MMP9, e) TIMP1, f) TIMP2, and g) RECK. The ECM-related genes clearly reprogramed in response to both LDHs. $* p<0.05 ; * * p<0.015 ; * *^{*} p<0.0002 ; * \cdots * * p<0.0001$ : Significant statistical difference when compared to control. 
activities. Thus, this balance of ECM-related gene reprograming may explain the difference of collagen I content response to both LDHs (Figure 4b).

\subsection{Both LDH Materials Promoted Expression of Osteogenic Marker Genes}

To evaluate osteogenic phenotype, we first found that both evaluated LDH materials could trigger intracellular pathways culminating in osteogenic markers of gene expressions. Both LDH samples promoted a significant increase of RUNX2 when compared to immediate control, where the cells were cultured at classical condition, and to the positive control (Figure 5a), where the cells were incubated with an osteogenic medium (see the Experimental Section for details). In addition, both LDHs upmodulated Osterix expression, when compared to immediate control (Figure $5 \mathrm{~b}$ ), but only $\mathrm{Mg}_{2} \mathrm{Al}-\mathrm{Cl}$ material promoted a very significant increase, when compared to both listed controls. Similar to RUNX2 and Osterix, Osteocalcin mRNA was also significantly upexpressed (Figure 5d). Importantly, alkaline phosphatase (ALP mRNA) was significantly upmodulated, reaching almost 50 -fold increase compared to unchallenged cells (Figure 5c). This result was validated by ALP staining (Figure 5i). In addition, Osteopontin (OPN mRNA), bone sialoprotein (BSP mRNA), bone morphogenetic proteins (BMP2), and $B M P 7$ genes were investigated. OPN mRNA was significantly upmodulated in response to $\mathrm{Zn}-\mathrm{Al} \mathrm{LDH}$ (sixfold changes increase) (Figure 5e). Importantly, BSP mRNA emerged as the
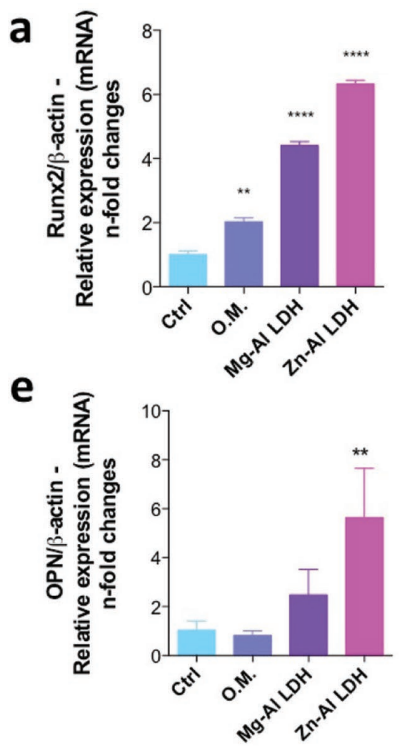

i

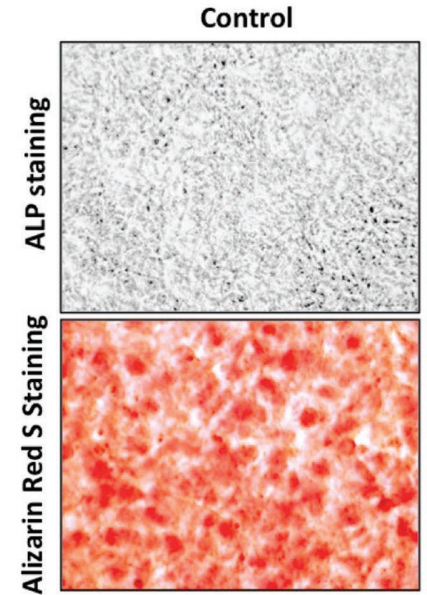

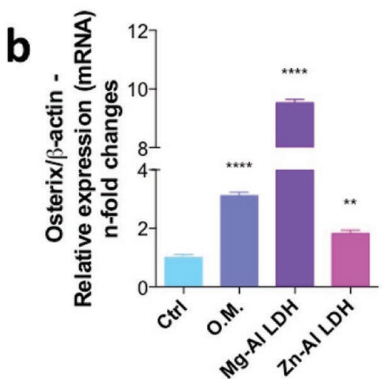

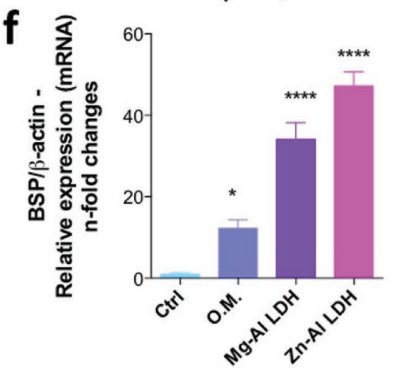

Osteogenic Medium

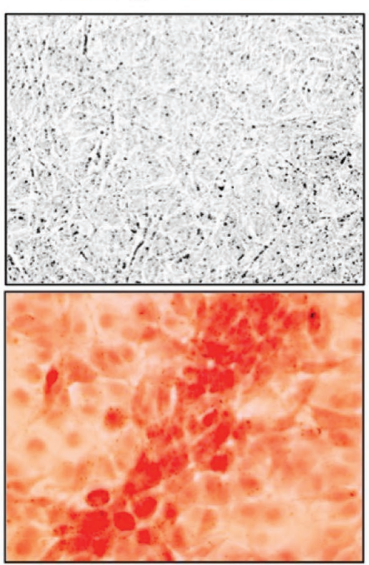

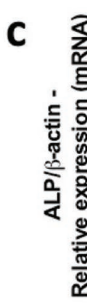

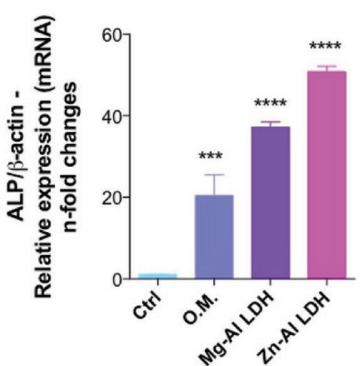

g
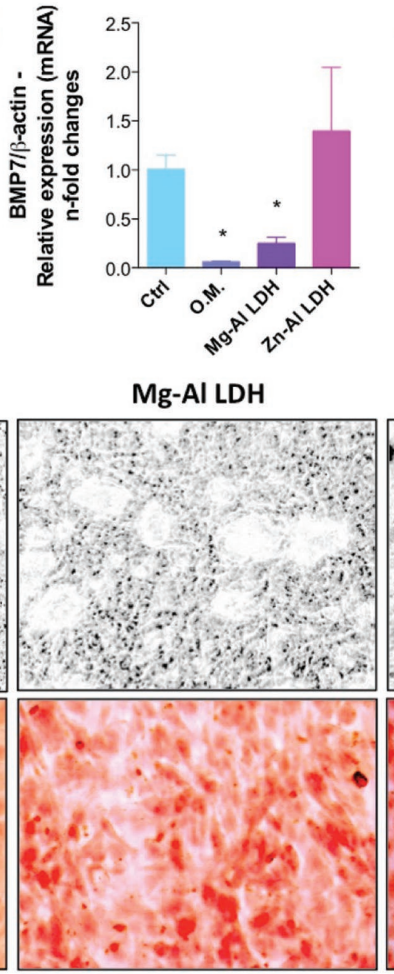

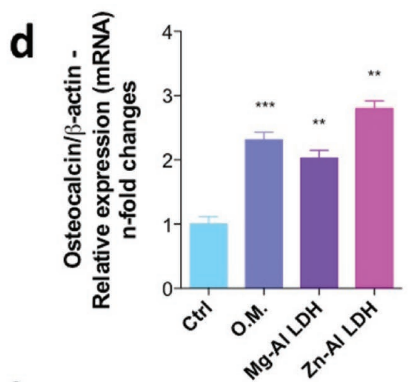

h

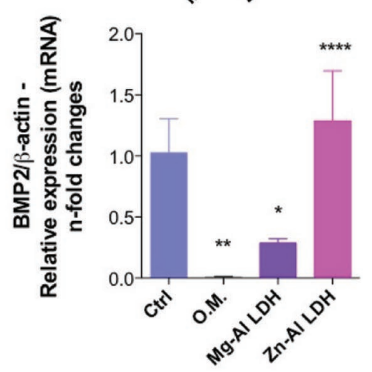

Zn-AI LDH

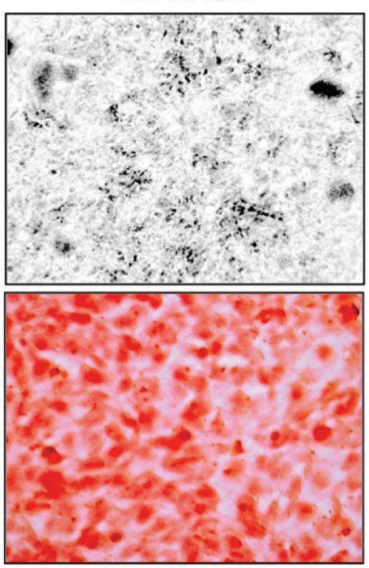

Figure 5. LDHs promote osteoblast differentiation. To evaluate the impact of LDH on osteoblast differentiation, we have added another control group, where the cells were maintained under a classical osteogenic medium treatment $\left[\beta\right.$-Glycerophosphate $\left(10 \times 10^{-3} \mathrm{M}\right)+$ Dexamethasone $\left(0.03 \mathrm{~g} \mathrm{~mL}^{-1}\right)+$ ascorbic acid $\left.\left(50 \mu \mathrm{g} \mathrm{mL}^{-1}\right)\right]$. The cells were cultured in each experimental condition up to $14 \mathrm{~d}$; then the samples were extracted, cDNA synthesis processed, the expressions of osteogenic markers genes evaluated. a) RUNX2 upmodulation in response to LDHs, as well as b) Osterix, c) ALP, and d) Osteocalcin. Additionally, e) Osteopontin (OPN) and f) bone sialoprotein (BSP) upmodulated in response to LDHs. Curiously, BSP had almost 50 -fold greater changes compared to unchallenged cells. In addition, we also investigated whether the BMP-induced autocrine signaling was required by analyzing the activation of g) BMP2 and h) BMP7 genes. Complementarily, we subjected challenged cells to ALP staining to elucidate i) the dis-

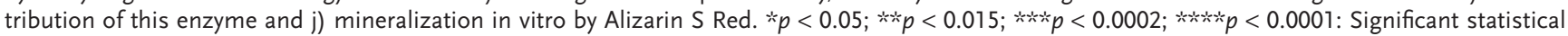
difference when compared to control. 
only bona fide candidate for hydroxyapatite nucleation, ${ }^{[31]}$ and this gene considerably increased in response to LDHs (greater than 40-fold increase for both LDHs) (Figure 5f). Both BMP genes presented very similar profile for both LDHs, which was higher in response to $\mathrm{Zn}-\mathrm{Al} \mathrm{LDH}$ (Figure $5 \mathrm{~g}, \mathrm{~h}$ ). Curiously, both BMP2 and BMP7 mRNAs were downregulated in response to osteogenic medium and $\mathrm{Mg}-\mathrm{Al} \mathrm{LDH}$, suggesting that there is no a autocrine BMP-induced stimulation of osteoblast differentiation (Figure 5g,h).

In addition, we stained the cells with Alizarin S red to estimate the in vitro mineralization. Our results showed that both LDH materials promoted in vitro mineralization similar to the positive control (Figure 5j). This result reinforces the activity of $B S P$ as a mineralizing nucleation protein (Figure $5 f$ ).

\subsection{LDH Promotes Upexpression of Receptor Activator of NF-KappaB Ligand (RANKL) and osteoprotegerin (OPG), Which Probably Interfere in Osteoclastogenesis}

Hematopoietic cell-derived osteoclasts depend on osteoblast metabolism, largely because osteoblasts express the RANKL, which is an essential cytokine for osteoclastogenesis. On the other hand, osteoblasts also produce OPG, a decoy receptor for RANKL, which inhibits osteoclast differentiation. Thus, the RANKL/RANK/OPG balance is a central axis to modulate osteoclastogenesis. ${ }^{[32]}$ Thus, we are interested whether LDHchallenged osteoblast can modulate both OPG and RANKL genes. Our results found a dynamic reprograming of both $O P G$ mRNA and RANKL mRNA in response to both LDHs. Both $\mathrm{Mg}-\mathrm{Al} \mathrm{LDH}$ and $\mathrm{Zn}-\mathrm{Al} \mathrm{LDH}$ promoted a considerable increase on OPG expression (Figure 6a), which was highest in response to $\mathrm{Zn}-\mathrm{Al} \mathrm{LDH}$, when compared to control group (Figure $6 \mathrm{a}$ ). In turn, RANKL mRNA was also modulated in response to both LDHs, but only Zn-Al LDH promoted a higher expression than other groups (Figure 6b). Importantly, the chemical-induced osteoblast differentiation by osteogenic medium (here used as a positive control of the osteogenic phenotype) does not seem to contribute to osteoclatogenesis, since both OPG mRNA and RANKL mRNA were downregulated compared to unchallenged osteoblasts (Figure 6a,b). Figure 6c illustrates the effect of LDH on osteoclastogenesis which stimulates osteoblast upregulation of RANKL and OPG.

Summarizing, Figure 7 illustrates the signaling pathways involved in response to LDH by osteoblasts. LDH promotes osteoblastic phenotype by upregulating osteogenic marker genes. In addition, we reported that LDH is an important stimulus for osteoclastogenesis, due to upregulation of OPG and RANKL expressions. Thus, LDH should be considered in bone disorders.
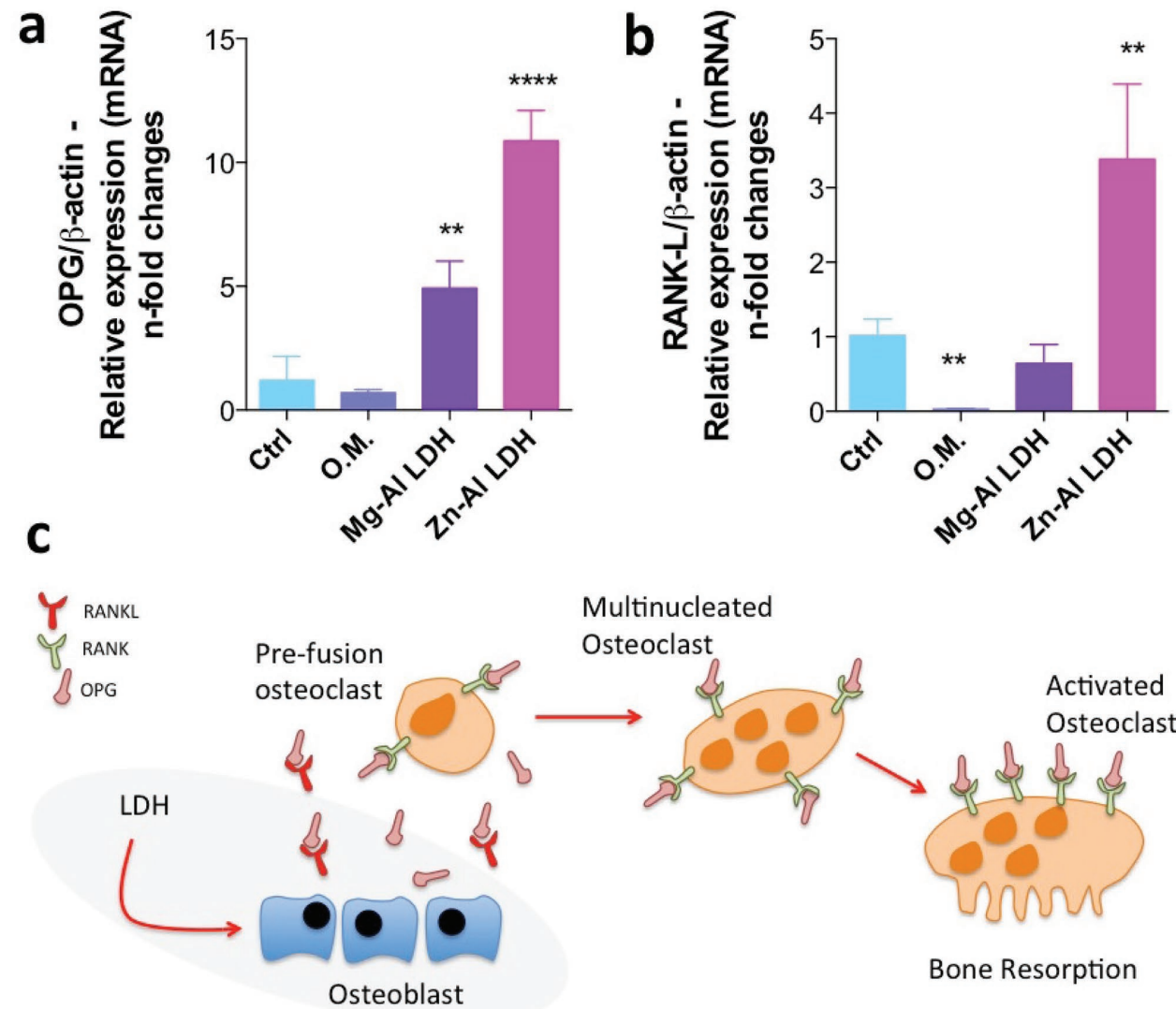

Multinucleated

steoclast

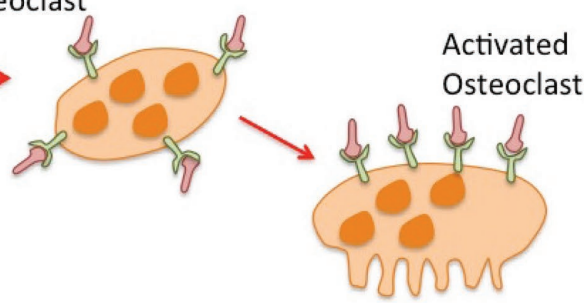

Bone Resorption

Figure 6. LDHs contribute in osteoblast-induced osteoclastogenesis. LDH-challenged osteoblasts were lysed and the total mRNA collected. After cDNA synthesis processing, the expressions of RANKL and OPG genes were evaluated. Both LDHs promoted upexpression of a) OPG, while RANKL was upexpressed only in response to b) Zn-Al LDH. c) RANKL and OPG are proteins released by osteoblast and related with osteoclastogenesis. $* * p<$ $0.015 ; * * * p<0.0001$ : Significant statistical difference when compared to control. 


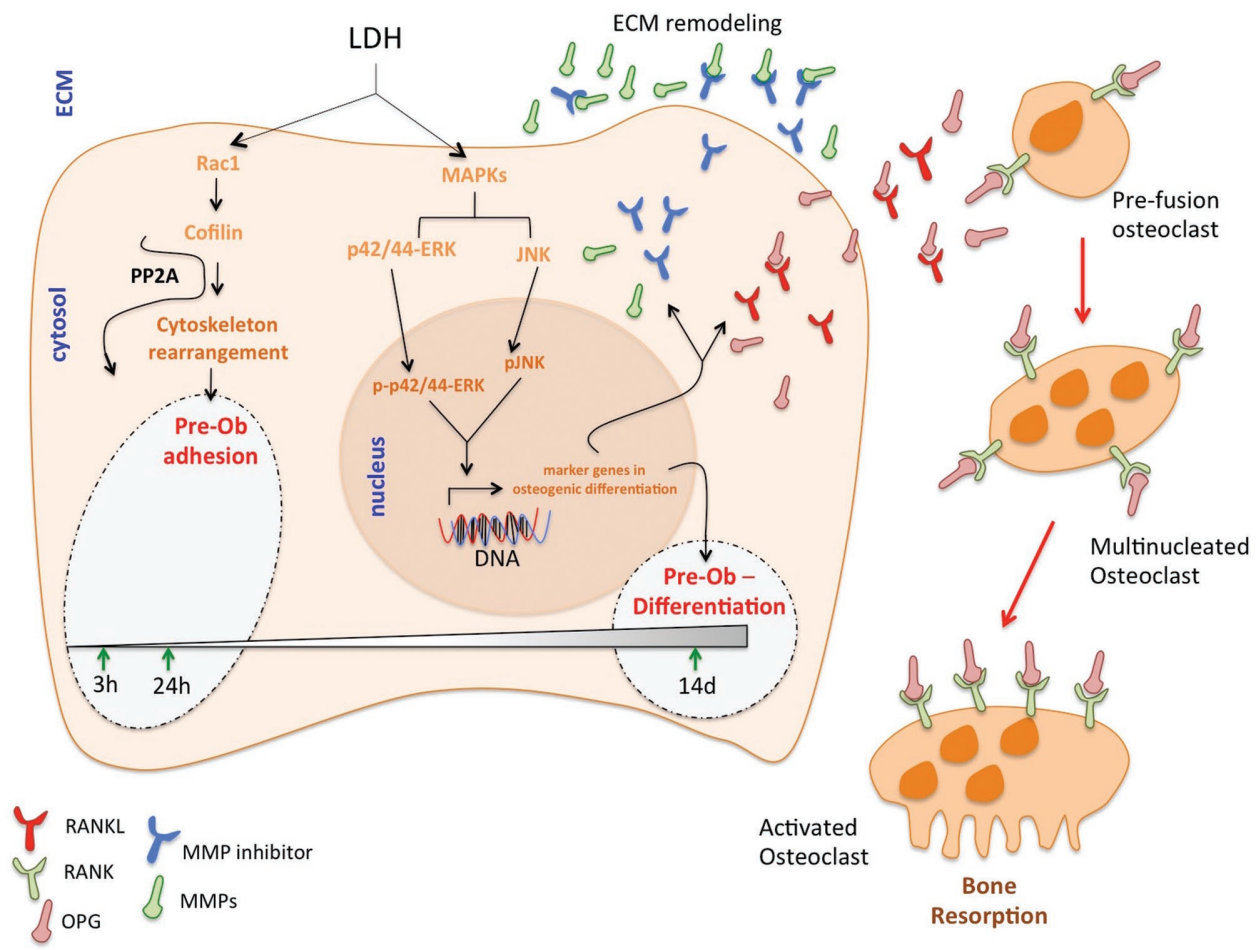

Figure 7. Schematic representation of the LDH-based intracellular signaling. LDHs promoted profound intracellular consequences on preosteoblast (pre-Ob) metabolism interfering in bone remodeling. First, LDHs promoted a significant modulation of cytoskeleton-related proteins, culminating in pre-Ob adhesion up to $24 \mathrm{~h}$ as a prerequisite for osteoblast differentiation. In addition, LDHs promote osteogenic phenotype at a MAPK-dependent signaling. As consequences, LDHs promote a dynamic ECM reprograming of remodeling-related genes and also contribute to osteoclastogenesis, since they upmodulate both RANKL and OPG in challenged osteoblast. The balance of RANKL and OPG orchestrates the fusion of mononuclear cells, culminating in specialized multinucleated osteoclasts that are responsible for promoting bone resorption. Summarizing, our data showed that LDH has an important effect on bone remodeling because it interferes with osteoblast and osteoclast.

\section{Discussion}

Novel strategies need to be investigated to clinically regenerate bone when there are critical-sized bone defects. Materials able to repair bone by stimulating an expression of marker genes in osteogenic differentiation are urgently necessary. We addressed this by investigating the effects of LDHs on pre-Ob performance. Immediately after their synthesis and characterization, the LDHs were used to challenge pre-Ob to verify their cytotoxicity, as recommended by ISO 10993-5:2016.

After identifying a safe concentration, we intensified the experiments for possible use in bone scaffold or drug-delivery nanomaterial for bone disorders. In sequence, we showed that LDH interferes pre-Ob adhesion by modulating a crucial intracellular pathway involved with cytoskeleton rearrangement, because important transducers as Rac-1, Cofilin, and PP2A were dynamically modulated. Rac-1 protein decreased in response to both evaluated LDHs, while phosphorylation of Cofilin significantly increased in response to both LDHs, presenting a very similar phosphorylation profile at both 3 and $24 \mathrm{~h}$. This phosphorylation balance of Cofilin can be explained by the strong inactivation of PP2A, ${ }^{[25,33,34]}$ because this Ser/Thr phosphatase was significantly phosphorylated in response to both LDHs. It is very known that PP2A modulates cytoskeleton rearrangement by guiding Cofilin phosphorylation at Serine 03. ${ }^{[35]}$ Elsewhere, we reported that intracellular pathways culminating in cytoskeleton rearrangement are very important to guarantee pre-Ob morphological changes in the beginning of the interaction with the substrate. ${ }^{[36]}$

After favoring cell adhesion, the promising novel candidates for application in bone disorders need to stimulate the differentiation of pre-Ob into mature osteoblasts. Thus, we investigated if $\mathrm{LDH}$ promoted osteoblast differentiation by upmodulating classical marker genes, such as the expression of early marker genes for osteoblast differentiation like RUNX2 and Osterix $(O S X)$ as late marker gene, osteocalcin (OCN). Our results found that both LDH materials promoted a significant increase of RUNX2 and OCN when compared to the experimental controls. OSX mRNA was also upmodulated by the both LDHs, but $\mathrm{Mg}_{2} \mathrm{Al}-\mathrm{Cl}$ was more significant compared to the both experimental controls. During the molecular sequence of bone formation, OSX is essential for osteoblast differentiation and intramembranous/endochondral bone formation, ${ }^{[37,38]}$ while RUNX2 is a bone-requisite transcription factor for the maturation of osteoblasts, whereas OSX is a downstream gene of RUNX2. ${ }^{[39-42]}$ Interestingly, Baek et al. ${ }^{[43]}$ reported that in OSXinactivated adult mice, RUNX2 expression was significantly increased. Although the exact mechanism is not yet clear, they suggested that the increased RUNX2 expression may be partly caused by the lack of OSX-mediated negative feedback mechanism and its expression may be controlled by the activation of the OSX-mediated gene. Therefore, it is reasonable to purpose 
that $\mathrm{Zn}_{2} \mathrm{Al}-\mathrm{Cl} \mathrm{LDH}$ interfered with the pre-Ob differentiation by a similar mechanism, as the RUNX2 mRNA was significantly upexpressed (almost threefold changes compared to control) while OSX mRNA was moderately expressed. As reported, bone matrix mineralization is widely regulated by the sequential marker gene expressions, which strictly depends on the stage of osteoblast differentiation. In addition, we subjected the cell to different staining to identify a profile of collagen deposition and late in vitro mineralization by performing Picrosirus and Alizarin S red, respectively. As previously noticed elsewhere, we found a difference in the collagen deposition and mineralization distinguishing both LDHs evaluated in a descriptive and qualitative way. However, other methodologies must be applied for more conclusive explanations of this matter (e.g., members of collagen family and BSP expressions by qPCR).

Additionally, investigation of intracellular pathways showed that MAPKs ERK and JNK were required in response to both LDHs, while AKT remained active. It is well-known that MAPK superfamily, including ERKs and JNKs, integrates signals from a wide range of extracellular stimuli, guiding important roles in cellular fate such as proliferation, differentiation, and cell death. For bone, Kim et al. ${ }^{[4]}$ indicated that osteoblast differentiation requires activating ERK and JNK, elucidating the molecular basis of the osteogenic effects of Fucoidan in mesenchyme stem cells; however, the JNK-MAPK pathway is by far the least understood MAPK pathway in osteoblasts, because the bone phenotype of JNK-deficient mice has yet to be reported. ${ }^{[26]}$ The elegant work by Matsuguchi et al. ${ }^{[45]}$ strongly suggests a critical role of JNK in the process of osteoblast differentiation.

MAPKs regulate key transcriptional mediators of osteoblast differentiation, with ERK and p38 MAPKs phosphorylating $R U N X 2$, the master regulator of osteoblast differentiation. ${ }^{[26]}$ The domains involved in ERK binding to RUNX2 have been mapped to a MAPK-binding D-domain, which is the C-terminal proline/serine/threonine-rich domain of $R U N X 2,{ }^{[46,47]}$ indicating that ERK activity may be differentially regulated in the context of specific osteoblast-relevant promoters. Further work is needed to identify both the range of genes bound by ERK and the functional importance of this association, as suggested by Greenblatt et al..[26]

We showed for the first time that both $\mathrm{LDH} \mathrm{Mg} \mathrm{Ml}_{2} \mathrm{Al}-\mathrm{Cl}$ and $\mathrm{Zn}_{2} \mathrm{Al}-\mathrm{Cl}$ promoted osteoblast differentiation by upmodulating osteoblastic classical marker genes (RUNX2, OSX, and OCN) by requiring the activation of JNK and ERK, while AKT remained in an active status. Additionally, because adequate osteoblastic differentiation is essential to maintain bone mass through life and strictly necessary for bone healing, LDHs must be explored as therapeutic nanomaterials to be applied into bone disorders as a scaffold for bone bioengineering or as a drug-delivery material to release topically specific molecules that facilitate local bone repair.

\section{Experimental Section}

Reagents: The antibodies used include Racl/Cdc42 Antibody (\#4651, 21 kDa); Cofilin (D59) Antibody (\#3318, 19 kDa); Phospho-Cofilin (Ser3) Antibody (\#3311, $19 \mathrm{kDa}$ ); glyceraldehyde 3-phosphate dehydrogenase (GAPDH) (14C10) Rabbit mAb (\#2118, $37 \mathrm{kDa}$ ); AKT Antibody (\#9272, $69 \mathrm{kDa})$; ERK (42, $44 \mathrm{kDa})$, p-ERK (42, $44 \mathrm{kDa})$; AKT (\#4685, $60 \mathrm{kDa})$;
Phospho-AKT (\#4060, 60 kDa)), and JNK (46, 54 kDa) (Phospho-MAPK Family Antibody Sampler Kit \#9910). Anti-PP2A alpha + beta antibody (ab137849) was purchased from Abcam (Cambridge, MA, USA) and Anti-PP2A alpha + beta antibody [phospho-Y119] from Cell Signaling (Danvers, MA, USA). All the other chemicals and reagents used in this study were of analytical grade, purchased from commercial sources.

Cell Culture and Conditions: Preosteoblasts were plated on cellculture dish plates with a density of 25000 cells $\mathrm{cm}^{-2}$ and cultured in minimum essential medium eagle- $\alpha$ modification ( $\alpha$-MEM) until they were confluent. The cells were maintained in osteogenic medium

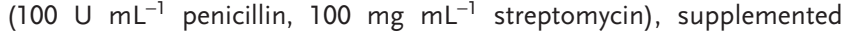
with ribonucleosides and deoxyribonucleosides with the addition of $\beta$-glycerophosphate $\left(10 \times 10^{-3} \mathrm{M}\right)$ and ascorbic acid $\left(50 \mu \mathrm{g} \mathrm{mL} \mathrm{L}^{-1}\right)$ for $\alpha \mathrm{MEM}$ (considered osteogenic medium, O.M.). Cells were cultured for $14 \mathrm{~d}$, with the medium changed every $3 \mathrm{~d}$. Cells were maintained at $37^{\circ} \mathrm{C}, 5 \% \mathrm{CO}_{2}$, and $95 \%$ humidity.

Cell Viability Was Measured by MTT Reduction: Briefly, cells ( 25000 cells $\mathrm{cm}^{-2}$ ) were plated $48 \mathrm{~h}$ prior to treatment in a 96 -well plate. After $24 \mathrm{~h}$ of plating, they were exposed to different concentrations of both LDHs up to $24 \mathrm{~h}$, then the cell viability was assessed by the MTT approach. The cell culture medium was removed, and immediately MTT (1 mg mL ${ }^{-1}$ ) was added, and they were kept in an incubator for an additional $4 \mathrm{~h}$. Then, the medium containing MTT was removed and $1 \mathrm{~mL}$ of dimethyl sulfoxide was added for solubilization of the blue dye formed by viable cells. ${ }^{[48]}$ Afterward, the absorbance was measured at $570 \mathrm{~nm}$ using a microplate reader (SYNERGY-HTX multi-mode reader, Biotek, USA).

Cell Adhesion Was Assayed by Violet Crystal: For the adhesion approach, MC3T3-E1 cells were treated properly with the both LDH samples up to $24 \mathrm{~h}$. Then, the cells were trypsinized, resuspended in conventional medium containing LDH, counted in hematological chamber, and plated (25000 cells $\mathrm{cm}^{-2}$ ) in 96 -well plates. ${ }^{[49]}$ After plating, cell adhesion was estimated by incorporation of crystal violet dye at the $3 \mathrm{~h}$ and $24 \mathrm{~h}$ postplating times.

Western Blotting: Respecting the different proposals, after 3 and $24 \mathrm{~h}$ for adhesion and $14 \mathrm{~d}$ for differentiation, the cells were lysed with Lysis buffer $\left(50 \times 10^{-3} \mathrm{~mol} \mathrm{~L}^{-1}\right.$, Tris- $\mathrm{HCl}, \mathrm{pH} 7.4,1 \%$ Tween $20,0.25 \%$ sodium deoxycholate, $150 \times 10^{-3} \mathrm{~mol} \mathrm{~L}^{-1} \mathrm{NaCl}, 1 \times 10^{-3} \mathrm{~mol} \mathrm{~L}^{-1}$ ethylene glycol tetraacetic acid (EGTA), $1 \times 10^{-3} \mathrm{~mol} \mathrm{~L}^{-1} \mathrm{O}$-Vanadate, $1 \times 10^{-3} \mathrm{~mol} \mathrm{~L}^{-1}$ $\mathrm{NaF}$, and protease inhibitors $10 \mu \mathrm{g} \mathrm{mL}^{-1}$ leupeptin and $1 \times 10^{-3} \mathrm{~mol} \mathrm{~L}^{-1}$ 4-aminoethyl fluorosulfonyl 4-hydrochloride hydrochloride). The samples were sonicated ( 1 pulse $\mathrm{s}^{-1}$, in a SONICS Vibra-Cell equipment) and maintained for $1 \mathrm{~h}$ on ice, when in each sequential $20 \mathrm{~min}$, the samples were vortexed. Then, protein extracts were pooled by centrifuging (14 $000 \mathrm{rpm}$ ) and the protein amount determined by the Lowry method. ${ }^{[50]}$ Finally, the protein extracts were added of $2 \times$ Laemmli buffer [ $2 \times$ sodium dodecyl sulfate (SDS), $100 \times 10^{-3} \mathrm{~mol} \mathrm{~L}^{-1}$ Tris- $\mathrm{HCl}[\mathrm{pH}$ 6.8], $200 \times 10^{-3} \mathrm{~mol} \mathrm{~L}^{-1}$ dithiothreitol (DTT), $4 \%$ SDS, $0.1 \%$ bromophenol blue, and $20 \%$ glycerol], and maintained for $5 \mathrm{~min}$ at $95{ }^{\circ} \mathrm{C}$. Once prepared, the samples were resolved on sodium dodecyl sulphatepolyacrylamide gel electrophoresis (SDS-PAGE) gel.

Osteogenic Phenotype: The osteogenic classical marker genes were analyzed by qPCR. For expression analysis, TriZol was added to the cultures and pelleted. After centrifugation, addition of chloroform and centrifugation, DNA, RNA, and protein phases were formed in the tube. RNA samples were quantified using plate reader (SYNERGY-HTX multimode reader, Biotek, USA). The next step was CDNA synthesis using the High-Capacity cDNA Reverse Transcription Kit - Applied Biosystems [2.0 $\mu \mathrm{L}$ of $10 \times$ RT Buffer, $0.8 \mu \mathrm{L} 25 \times$ dNTP Mix $\left(100 \times 10^{-3} \mathrm{~mol} \mathrm{~L}^{-1}\right)$, $2.0 \mu \mathrm{L} 10 \times$ RT Randon Primers, $1.0 \mu \mathrm{L}$ MultiScrible Reverse Transcriptase, $4.2 \mu \mathrm{L}$ Nuclease-Free $\mathrm{H}_{2} \mathrm{O}$ ], then $200 \mathrm{ng} \mu \mathrm{L}^{-1}$ of each sample was added for CDNA synthesis in a 96-well plate and taken to the QuantStudio 3 (Applied Biosystems). After this initial process, the material was collected and evaluated for the expression (Table 1). In addition, histochemical staining for ALP activity in the cells was determined using Sigma Fast BCIP/NBT Tablets (B5655) according to the manuals.

In Vitro Picrosirius Staining: Preosteoblasts were plated at a density of $8 \times 10^{4}$ cells $\mathrm{mL}^{-1}$ in 24 -well plates and in semiconfluence treated 
Table 1. Expression primer sequences and PCR cycle conditions.

\begin{tabular}{|c|c|c|c|}
\hline Gene & Primer & $5^{\prime}-3^{\prime}$ Sequence & Reaction condition \\
\hline \multirow[t]{2}{*}{ MMP2 } & Forward & AACTTTCAGAAGGATCGCAAGT & $95^{\circ} \mathrm{C}-3 \mathrm{~s} ; 60^{\circ} \mathrm{C}-8 \mathrm{~s} ; 72{ }^{\circ} \mathrm{C}-20 \mathrm{~s}$ \\
\hline & Reverse & TGCCACCCATCGTAAACAA & \\
\hline \multirow[t]{2}{*}{ MMPg } & Forward & TGTGCССTCGAACTCACACGAC & $95^{\circ} \mathrm{C}-3 \mathrm{~s} ; 62{ }^{\circ} \mathrm{C}-8 \mathrm{~s} ; 72{ }^{\circ} \mathrm{C}-20 \mathrm{~s}$ \\
\hline & Reverse & АСGTCGTCСАССTGGTTСАССT & \\
\hline \multirow[t]{2}{*}{ TIMP1 } & Forward & АТССТСТTСTTGCTATСACTG & $95^{\circ} \mathrm{C}-5 \mathrm{~s} ; 60^{\circ} \mathrm{C}-10 \mathrm{~s} ; 72^{\circ} \mathrm{C}-15 \mathrm{~s}$ \\
\hline & Reverse & GGTCTCGTTGATTTCTGGG & \\
\hline \multirow[t]{2}{*}{ TIMP2 } & Forward & GCAACAGGCGTTTTGCAATC & $95^{\circ} \mathrm{C}-3 \mathrm{~s} ; 60^{\circ} \mathrm{C}-8 \mathrm{~s} ; 72{ }^{\circ} \mathrm{C}-20 \mathrm{~s}$ \\
\hline & Reverse & CGCAATCCACCTCCTTCTCG & \\
\hline \multirow[t]{2}{*}{ RECK } & Forward & ССТСAGTGAGCACAGTTCAGA & $95^{\circ} \mathrm{C}-3 \mathrm{~s} ; 60^{\circ} \mathrm{C}-8 \mathrm{~s} ; 72{ }^{\circ} \mathrm{C}-20 \mathrm{~s}$ \\
\hline & Reverse & ССTGTGGCATCCACGAAACT & \\
\hline \multirow[t]{2}{*}{ Col 1A1 } & Forward & ATGACGTCATCTGTGACGACAC & $95^{\circ} \mathrm{C}-3 \mathrm{~s} ; 62{ }^{\circ} \mathrm{C}-8 \mathrm{~s} ; 72{ }^{\circ} \mathrm{C}-20 \mathrm{~s}$ \\
\hline & Reverse & TTCTTGGTCGGTCGGTCAC & \\
\hline \multirow[t]{2}{*}{ Col 3A1 } & Forward & GACCTGAAATTCTGCCATCC & $95^{\circ} \mathrm{C}-3 \mathrm{~s} ; 62^{\circ} \mathrm{C}-8 \mathrm{~s} ; 72{ }^{\circ} \mathrm{C}-20 \mathrm{~s}$ \\
\hline & Reverse & GCATGTTTCCCCAGTTTCC & \\
\hline \multirow[t]{2}{*}{$B S P$} & Forward & GTACCGGCCACGCTACTTTCT & $95^{\circ} \mathrm{C}-3 \mathrm{~s} ; 60{ }^{\circ} \mathrm{C}-8 \mathrm{~s} ; 72{ }^{\circ} \mathrm{C}-20 \mathrm{~s}$ \\
\hline & Reverse & GTTGACCGCCAGCTCGTTTT & \\
\hline \multirow[t]{2}{*}{$B M P 2$} & Forward & GGTCACAGATAAGGCCATTGC & $95^{\circ} \mathrm{C}-3 \mathrm{~s} ; 60^{\circ} \mathrm{C}-8 \mathrm{~s} ; 72{ }^{\circ} \mathrm{C}-20 \mathrm{~s}$ \\
\hline & Reverse & GCTTCCGCTGTTTGTGTTTG & \\
\hline \multirow[t]{2}{*}{$B M P 7$} & Forward & TGACAAACAATTCTTCCACCCTCGA & $95^{\circ} \mathrm{C}-5 \mathrm{~s} ; 72{ }^{\circ} \mathrm{C}-10 \mathrm{~s} ; 72^{\circ} \mathrm{C}-15 \mathrm{~s}$ \\
\hline & Reverse & GTAATACGACTCACTATAGGGCAGGGTTCCTTGTTCTGGGGT & \\
\hline \multirow[t]{2}{*}{ OPG } & Forward & CAGAGACTAATAGATCAAAGGCAGG & $95^{\circ} \mathrm{C}-3 \mathrm{~s} ; 60^{\circ} \mathrm{C}-8 \mathrm{~s} ; 72{ }^{\circ} \mathrm{C}-20 \mathrm{~s}$ \\
\hline & Reverse & ATCAAGTCTCACCTGAGAAGAACC & \\
\hline \multirow[t]{2}{*}{ RANKL } & Forward & СGСТСTGTTССТGTACTTTCGAGCG & $95^{\circ} \mathrm{C}-3 \mathrm{~s} ; 60^{\circ} \mathrm{C}-8 \mathrm{~s} ; 72{ }^{\circ} \mathrm{C}-20 \mathrm{~s}$ \\
\hline & Reverse & TCGTCCTCCCTCCTTTCATCAGGTT & \\
\hline \multirow[t]{2}{*}{$R \cup N X 2$} & Forward & GGACGAGGCAAGAG 1 II CA & $95^{\circ} \mathrm{C}-3 \mathrm{~s} ; 55^{\circ} \mathrm{C}-8 \mathrm{~s} ; 72{ }^{\circ} \mathrm{C}-20 \mathrm{~s}$ \\
\hline & Reverse & TGGTGCAGAGTTCAGGGAG & \\
\hline \multirow[t]{2}{*}{ ALP } & Forward & GAAGTCCGTGGGCATCGT & $95^{\circ} \mathrm{C}-3 \mathrm{~s} ; 55^{\circ} \mathrm{C}-8 \mathrm{~s} ; 72{ }^{\circ} \mathrm{C}-20 \mathrm{~s}$ \\
\hline & Reverse & CAGTGCGGTTCCAGACATAG & \\
\hline \multirow[t]{2}{*}{ Osteocalcin $(O C N)$} & Forward & AGACTCCGGCGCTACCTT & $95^{\circ} \mathrm{C}-3 \mathrm{~s} ; 55^{\circ} \mathrm{C}-8 \mathrm{~s} ; 72{ }^{\circ} \mathrm{C}-20 \mathrm{~s}$ \\
\hline & Reverse & CTCGTCACAAGCAGGGTTAAG & \\
\hline \multirow[t]{2}{*}{ Osterix $(O S X)$} & Forward & ССС TTC ССТ САС TCA TTT СC & $95^{\circ} \mathrm{C}-5 \mathrm{~s} ; 56^{\circ} \mathrm{C}-10 \mathrm{~s} ; 72{ }^{\circ} \mathrm{C}-15 \mathrm{~s}$ \\
\hline & Reverse & CAA CCG CCT TGG GCT TAT & \\
\hline \multirow[t]{2}{*}{ Osteopontin } & Forward & TTTGCTTTTCССTGTTTGGC & $95^{\circ} \mathrm{C}-5 \mathrm{~s} ; 60^{\circ} \mathrm{C}-10 \mathrm{~s} ; 72^{\circ} \mathrm{C}-15 \mathrm{~s}$ \\
\hline & Reverse & CAGTCACTTTCACCGGGAGG & \\
\hline \multirow[t]{2}{*}{$\beta$-actin } & Forward & TCTTGGGTATGGAATCCTGTC & $95^{\circ} \mathrm{C}-3 \mathrm{~s} ; 55^{\circ} \mathrm{C}-8 \mathrm{~s} ; 72{ }^{\circ} \mathrm{C}-20 \mathrm{~s}$ \\
\hline & Reverse & AGGTCTTTACGGATGTCAACG & \\
\hline
\end{tabular}

with the different LDH materials up to $14 \mathrm{~d}$. For qualitative analysis of collagen content, the cells were washed in phosphate buffered saline (PBS) and fixed in 4\% paraformaldehyde for $1 \mathrm{~h}$ and then stained for $90 \mathrm{~min}$ in a $0.1 \%$ solution of red Sirius in saturated aqueous picric acid, $\mathrm{pH}$ 2. Next, the cells were washed for $2 \min$ in $0.01 \mathrm{~N} \mathrm{HCl}$ and counterstained with Harris Hematoxylin for $6 \mathrm{~min}$, washed in ethanol $70 \%$, dehydrated, and mounted using Permount. For the conventional fluorescence microscope, images were acquired in the inverted microscope Axio Vert.A1 (Zeiss, Germany).

In Vitro Hematoxylin \& Eosin Staining: Preosteoblasts were plated at a density of $8 \times 10^{4}$ cells $\mathrm{mL}^{-1}$ in 24 -well plates and in semiconfluence treated with the different LDH materials up to $14 \mathrm{~d}$. For a morphological analysis of the cells, hematoxylin \& eosin technology was used, where the cells were previously fixed in phosphate-buffered $4 \%$ paraformoldehyde for $40 \mathrm{~min}$, washed with water for $7 \mathrm{~min}$, incubated for $5 \mathrm{~min}$ in hematoxylin, washed with water for $3 \mathrm{~min}$, and stained with eosin for $7 \mathrm{~min}$. Then, the coverslips were dehydrated and photographed under a conventional optical microscope Axio Vert.A1 (Zeiss, Germany).

In Vitro Alizarin S Red Staining: Preosteoblasts were plated at a density of $8 \times 10^{4}$ cells $\mathrm{mL}^{-1}$ in 24-well plates and in semiconfluence treated with the different LDH materials, as previously described, up to $14 \mathrm{~d}$. The medium was changed every $3 \mathrm{~d}$. In vitro mineralization was measured during osteoblast differentiation process by alizarin Red $S$ staining. The culture medium was gently removed and washed with warm PBS. 
Thereafter, the PBS was removed, and $0.5 \mathrm{~mL}$ of $10 \%$ formalin was added for cell fixation. The plate was held in that solution for $30 \mathrm{~min}$ at room temperature. After this period, formalin was removed, and Alizarin solution (1\%) added in the cultures, and then they were incubated in the dark chamber for additional $45 \mathrm{~min}$. The cells were washed five times in PBS. Finally, cell images were acquired by using an inverted microscope (Zeiss, Germany).

Statistical Analysis: Results were plotted as mean \pm standard deviation and verified using one-way analysis of variances (ANOVA) (nonparametric) with Tukey's post-test, to compare all pairs of groups. In this case, $p<0.05$ was considered statistically significant and $p<0.0001$ considered highly significant. The software used was GraphPad Prism 6. For particle counting, Imagel Software was used to determine the number of points in the area recorded in the photo, and for the statistical analysis, the groups were standardized by the percentage of the control.

\section{Acknowledgements}

The authors would like to thank the FAPESP (Proc. 2014/22689-3; 2011/50318-1) and the CNPq for the financial support. The authors are thankful to Dr. Vanessa R. R. Cunha for preparation of samples.

\section{Conflict of Interest}

The authors declare no conflict of interest.

\section{Keywords}

differentiation, double metal hydroxides, hydrotalcite-like materials, layered double hydroxides, nanoparticles, osteoblasts

Received: June 2, 2017

Revised: October 14, 2017

Published online: December 27, 2017

[1] S. Gemini-Piperni, E. R. Takamori, S. C. Sartoretto, K. B. S. Paiva, J. M. Granjeiro, R. C. de Oliveira, W. F. Zambuzzi, Arch. Biochem. Biophys. 2014, 561, 88.

[2] A. Teti, Curr. Osteoporosis Rep. 2011, 9, 264

[3] S. Yazar, C.-H. Lin, F.-C. Wei, Plast. Reconstr. Surg. 2004, 114, 1457.

[4] P. Habibovic, K. de Groot, J. Tissue Eng. Regener. Med. 2007, 1, 25.

[5] A. Del Fattore, A. Teti, N. Rucci, Front. Biosci., Elite Ed. 2012, 4, 2302.

[6] A. Marumoto, R. Milani, R. A. da Silva, C. J. da Costa Fernandes, J. M. Granjeiro, C. V. Ferreira, M. P. Peppelenbosch, W. F. Zambuzzi, Bone 2017, 103, 55.

[7] C. J. Serna, J. L. White, S. L. Hem, J. Pharm. Sci. 1978, 67, 324.

[8] K. H. Holtermuller, M. Liszkay, I. Bernard, W. Haase, Z. Gastroenterol. 1992, 30, 717.

[9] A. Tarnawski, R. Pai, R. Itani, F. A. Wyle, Digestion 1999, 60, 449.

[10] A. S. Tarnawski, M. Tomikawa, M. Ohta, I. J. Sarfeh, J. Physiol. 2000, 94, 93.

[11] Z. Gu, J. J. Atherton, Z. P. Xu, Chem. Commun. 2015, 51, 3024.

[12] S.-J. Choi, J.-H. Choy, Nanomedicine 2011, 6, 803.

[13] R. Liang, M. Wei, D. G. Evans, X. Duan, Chem. Commun. 2014, 50, 14071.

[14] B. Saifullah, M. Z. B. Hussein, Int. J. Nanomed. 2015, 10, 5609.

[15] Y. Kuthati, R. K. Kankala, C.-H. Lee, Appl. Clay Sci. 2015, 112, 100.
[16] V. R. R. Cunha, P. A. D. Petersen, M. B. Gonçalves, H. M. Petrilli, C. Taviot-Gueho, F. Leroux, M. L. A. Temperini, V. R. L. Constantino, Chem. Mater. 2012, 24, 1415.

[17] O. M. Gil, M. A. Rocha, V. R. L. Constantino, I. H. J. Koh, D. L. A. de Faria, Vibrational Spectroscopy 2016, 87, 60.

[18] M. A. Rocha, P. A. D. Petersen, E. Teixeira-Neto, H. M. Petrilli, F. Leroux, C. Taviot-Guehode, V. R. L. Constantino, RSC Adv. 2016, 6, 16419.

[19] V. R. R. Cunha, V. A. Guilherme, E. de Paula, D. R. de Araujo, R. O. Silva, J. V. R. Medeiros, J. R. S. A. Leite, P. A. D. Petersen, M. Foldvari, H. M. Petrilli, Mater. Sci. Eng., C 2016, 58, 629.

[20] V. R. R. Cunha, R. B. de Souza, A. M. C. R. P. da Fonseca Martins, I. H. J. Koh, V. R. L. Constantino, Sci. Rep. 2016, 6, 30547.

[21] G. Kapusetti, R. R. Mishra, S. Srivastava, N. Misra, V. Singh, P. Roy, S. K. Singh, C. Chakraborty, S. Malik, P. Maiti, J. Mater. Chem. B 2013, 1, 2275.

[22] Y.-X. Chen, R. Zhu, Z. Xu, Q.-F. Ke, C.-Q. Zhang, Y.-P. Guo, J. Mater. Chem. B 2017, 5, 2245.

[23] S. Bertazzo, W. F. Zambuzzi, D. D. P. Campos, C. V. Ferreira, C. A. Bertran, Clin. Oral Implants Res. 2010, 21, 1411.

[24] S. Bertazzo, W. F. Zambuzzi, D. D. P. Campos, T. L. Ogeda, V. Ferreira C, C. A. Bertran, Colloids Surf., B 2010, 78, 177.

[25] W. F. Zambuzzi, A. Bruni-Cardoso, J. M. Granjeiro, M. P. Peppelenbosch, H. F. de Carvalho, H. Aoyama, C. V. Ferreira, J. Cell. Biochem. 2009, 108, 134.

[26] M. B. Greenblatt, J.-H. Shim, L. H. Glimcher, Annu. Rev. Cell Dev. Biol. 2013, 29, 63.

[27] P. Lu, K. Takai, V. M. Weaver, Z. Werb, Cold Spring Harbor Perspect. Biol. 2011, 3, 12.

[28] A. C. C. de Oliveira Demarchi, W. F. Zambuzzi, K. B. S. Paiva, M. D. G. da Silva-Valenzuela, F. D. Nunes, R. D. C. S. Figueira, R. M. Sasahara, M. A. A. Demasi, S. M. B. Winnischofer, M. C. Sogayar, J. M. Granjeiro, Cell Tissue Res. 2010, 340, 61.

[29] W. F. Zambuzzi, C. L. Yano, A. D. M. Cavagis, M. P. Peppelenbosch, J. M. Granjeiro, C. V. Ferreira, Mol. Cell. Biochem. 2009, 322, 143.

[30] K. B. S. Paiva, W. F. Zambuzzi, T. Accorsi-Mendonca, R. Taga, F. D. Nunes, M. C. Sogayar, J. M. Granjeiro, J. Mol. Histol. 2009, 40, 201.

[31] B. Ganss, R. H. Kim, J. Sodek, Crit. Rev. Oral Biol. Med. 1999, 10, 79.

[32] Y. Kobayashi, N. Udagawa, N. Takahashi, Crit. Rev. Eukaryotic Gene Expression 2009, 19, 61.

[33] N. V. Oleinik, N. I. Krupenko, S. A. Krupenko, Oncogene 2010, 29, 6233.

[34] A. Blangy, H. Touaitahuata, G. Cres, G. Pawlak, PLoS One 2012, 7, e45909.

[35] W. F. Zambuzzi, C. V. Ferreira, J. M. Granjeiro, H. Aoyama, J. Biomed. Mater. Res., Part A 2011, 97, 193.

[36] S. Gemini-Piperni, R. Milani, S. Bertazzo, M. Peppelenbosch, E. R. Takamori, J. M. Granjeiro, C. V. Ferreira, A. Teti, W. F. Zambuzzi, Biotechnol. Bioeng. 2014, 111, 1900.

[37] J. Lu, S. Qu, B. Yao, Y. Xu, Y. Jin, K. Shi, Y. Shui, S. Pan, L. Chen, C. Ma, Oncotarget 2016, 7, 37471 .

[38] A. M. Buo, R. E. Tomlinson, E. R. Eidelman, M. Chason, J. P. Stains, J. Bone Miner. Res. 2017, 32, 1727.

[39] C. A. Yoshida, H. Yamamoto, T. Fujita, T. Furuichi, K. Ito, K. Inoue, K. Yamana, A. Zanma, K. Takada, Y. Ito, T. Komori, Genes Dev. 2004, 18, 952.

[40] J. Y. Choi, J. Pratap, A. Javed, S. K. Zaidi, L. Xing, E. Balint, S. Dalamangas, B. Boyce, A. J. V. Wijnen, J. B. Lian, J. L. Stein, S. N. Jones, G. S. Stein, Proc. Natl. Acad. Sci. USA 2001, 98, 8650.

[41] J. E. Aubin, E. Bonnelye, Medscape Womens Health 2000, 5, 5.

[42] T. Komori, J. Cell. Biochem. 2005, 95, 445.

[43] W. Y. Baek, M. A. Lee, J. W. Jung, S. Y. Kim, H. Akiyama, B. de Crombrugghe, J. E. Kim, J. Bone Miner. Res. 2009, 24, 1055.

[44] B. S. Kim, H. J. Kang, J. Y. Park, J. Lee, Exp Mol Med. 2015, 47, e128. 
[45] T. Matsuguchi, N. Chiba, K. Bandow, K. Kakimoto, A. Masuda, T. Ohnishi, J. Bone Miner. Res. 2009, 24, 398.

[46] C. Ge, Q. Yang, G. Zhao, H. Yu, K. L. Kirkwood, R. T. Franceschi, J. Bone Miner. Res. 2012, 27, 538 .

[47] G. Xiao, D. Jiang, R. Gopalakrishnan, R. T. Franceschi, J. Biol. Chem. 2002, 277, 36181
[48] T. Mosmann, J. Immunol. Methods 1983, 65, 55.

[49] F. Bezerra, M. R. Ferreira, G. N. Fontes, C. J. da Costa Fernandes, D. C. Andia, N. C. Cruz, R. A. da Silva, W. F. Zambuzzi, Biotechnol. Bioeng. 2017, 114, 1888.

[50] E. C. Lowry, J. M. Blumberg, R. L. Rhea, J. P. Ranson, U. S. Armed Forces Med. J. 1951, 2, 265. 